\title{
Megachurches in Russia and other Parts of the Former Soviet Union
}

\author{
Torsten Löfstedt
}

\section{1 \\ Introduction}

For most of the twentieth century Russia was part of the Soviet Union, an atheistic state that actively opposed religion. The situation changed abruptly under glasnost policies of Mikhail Gorbachev in the late 1980s, when Russians were allowed to again practice religion freely. In the late 1980 s and early $1990 \mathrm{~s}$ hundreds of Protestant congregations were established in areas that had largely lacked Christian presence for the greater part of the century. Instrumental in these successful church planting efforts were a few especially dynamic and rapidly growing congregations, many of which eventually became megachurches. There is little research on megachurches in Russia and exact numbers of worshippers are not available, but the atlases of religious life in Russia edited by Bourdeaux and Filatov (2005, 2006, 2009) and Filatov $(2014,2016)$ offer some indication of the most significant Protestant congregations in the country. The largest Protestant congregations in this area include: Good News Church (Moscow, 3,500 attend), Word of Life (Moscow, 4,000 members in 2012), New Testament (Perm, 3,750 members in 2012); Philadelphia (Izhevsk); Bethany (Krasnodar, 5,000 members in 2014); Hosanna Church (Makhachkala); Church of the Covenant (Novosibirsk, 2,000 worshippers in 1999); Grace of Jesus Christ (Volgograd); Church of God a.k.a. New Generation (Yaroslavl, 3,000 members 2012). In addition to these I refer to select megachurches in other former Soviet republics which are of particular interest. They are: Word of Life (Yerevan, Armenia, 10,000 members 2012); New Generation (Riga, Latvia); Word of Life (Donetsk, Ukraine; 5,000 members before the war in E. Ukraine 2014); Embassy of the Blessed Kingdom of God (Kiev, Ukraine, 25,000 members in 2010); Hillsong Church (Kiev, Ukraine, 3,000 attend); Victory Christian Church (Kiev, Ukraine, 3,0oo attend). Some of these churches have recently seen significant loss of members for various reasons. Two especially significant examples of shrinking churches, Word of Life (Donetsk) and Hosanna (Makhachkala), will be discussed below. While not all congregations 
necessarily serve a minimum of 2,00o people per week, these churches share a number of common features which set them apart from other churches in Russia and which merit their being studied together. They are all located in large metropolitan areas. Most were founded in the early 1990s, and are affiliated with one or the other of the two leading Pentecostal denominations. They have all been very active in church planting and support a wide range of ministries. Before looking at some of their characteristics, I will give a historical overview.

Most of the megachurches in Russia and other former Soviet states were established in the early 1990s, that is, at the time that the Soviet Union was coming to an end and shortly thereafter. This was a period when thousands of new congregations were established; most remained small, but some grew remarkably quickly.

The religious situation in the former Soviet Union is unique. The vast majority of the population was unchurched as a result of 70 years of Communist rule. While the majority of Russians today identify as Russian Orthodox, most are not active in any church and have very little knowledge of Christianity. Although their number has grown rapidly after the Soviet era, Protestants still form a small minority of the population of Russia. Lunkin (2014) estimated that there were three million Protestants in Russia in 2014 out of a population of 142.5 million; they make up a little more than 2 population of the population. This has consequences for their relationship to the state and thus their ability to build worship centres and develop ministries.

In the first decade of Soviet rule, Evangelical churches grew, but religious freedom came to be severely curtailed with the promulgation of the Laws on Religious Association in 8 April 1929, which were in force (with some modifications) until 1990 (Wanner 2007: 49). During most of the Soviet era there were considerable restrictions of the freedom of religion; churches were not allowed to own property (it was seized by the state) and unregistered religious activity was a criminal offence. Government officials arrested, imprisoned and even killed religious leaders (Franchuk 2001-2003). Only a few evangelical congregations could operate openly. These generally kept a low profile and did not engage in proselytism. Such congregations tended to isolate themselves as much as possible from others and developed sectarian tendencies; their members had strict moral codes on various issues. For example, Soviet evangelicals 
refused armed service and sought alternative placements, such as in construction brigades (Wanner 2004: 750). In evangelical circles, smoking, drinking and dancing were considered sins. Those who smoked or drank alcohol risked being excluded from the church. Congregations had strict dress codes and clear gender roles; women were expected to cover their heads in church and could not serve as pastors (Löfstedt 2012).

Although there was widespread repression throughout the Soviet Union, in some parts of the country people enjoyed greater religious freedom. This was the case for the Ukrainian and Belarussian Republics. The western parts of these republics had been a part of Poland 1921-1940 and there Protestant churches had been able to develop in relative peace. Even under Soviet rule people in these regions were better able to maintain their religious practices. In consequence, as Wanner notes, at the time the Soviet Union came to an end, half of all of its registered Pentecostals, or 350,00o people, lived in Ukrainian SSR (Wanner 2009: 91).

In the waning years of the Soviet Union the religious situation in Russia changed rapidly. Mikhail Gorbachev, who was to be the last general secretary of the Communist Party of the USSR, encouraged the celebration of a millennium of Russian Christianity in 1988. Sensing a change in attitude, religious organisations in Russia began to practice more openly. On 1 October 1990, two months before USSR was dissolved, the Soviet law "On Freedom of Conscience and Religious Organizations" was promulgated, replacing the laws of religious association from 1929. It now became legal to openly evangelise for the first time in over 60 years. When the Soviet Union was disbanded the same freedoms were guaranteed by newly established Russian laws, such as the law "On Freedom of Belief", 25 October 1990. These rights were affirmed in the Russian Constitution (1993) (Knox 2005: 76-77). Hundreds of Ukrainian evangelicals (who spoke Russian fluently, as they had all learned it in school during the Soviet era, and were accustomed to reading scripture in church using the Russian Synodal Translation) were sent by local churches and mission organisations across the open border to Russia as missionaries to establish new churches. Missionaries came to Russia from abroad as well, including from the USA, Western Europe and Korea (Knox 2005: 86).

In the initial period of new religious freedom in Russia (1990-1994), there was great interest in Christianity and things western, and western missionaries had no trouble organising successful evangelistic campaigns (Knox 2005: 100). Established Pentecostal congregations and Pentecostal missionaries from Ukraine did much of the ground work and follow-up work connected to these campaigns. Many new congregations, including some that eventually developed into megachurches, were founded in the wake of these campaigns. 
Missionaries from Ukraine were especially successful at founding congregations; founding pastors of the large Protestant congregations New Testament in Perm (Eduard Grabovenko and Pavel Khuda, founders 1991), Philadelphia in Izhevsk (Pavel Zhelnovakov, founder 1992), Church of the Covenant in Novosibirsk (Vitalii Maksimyuk, founder 1991), Grace of Jesus Christ in Volgograd (Alexei Rudenkii, founder 1991), Church of God in Yaroslavl (Viktor Tatach, founder 1991) were all born in what is now Ukraine. These pastors are all now firmly established in Russia and have trained Russians to serve with them in the ministry.

While western missionaries generally only served for short periods of time in Russia, in a few cases these missionaries stayed on as pastors of large congregations. One such example is the Norwegian-born Mats-Ola Ishoel who moved to Moscow in 1996 with the Swedish-based Russia Inland Mission and came to serve as head pastor of Word of Life (Moscow), replacing the Swedish missionary Christian Åkerhielm. Another example is Rick Renner who first moved to Latvia from Oklahoma in 1991 and founded Good News Church in Riga in 1992. He later moved to Moscow, where he founded another Good News congregation in 2000, and where he is still serving as head pastor.

At the same time as evangelicals from Ukraine moved to Russia to establish congregations, two especially dynamic congregations were founded in Ukraine by Africans, who had originally moved there to study at the universities: the Embassy of God (Kiev), founded in 1994 by Sunday Adelaja, originally from Nigeria, who had moved to the Soviet Union to study journalism, and Victory Christian Church, established in 1992 by Henry Madava, from Zimbabwe, who had studied civil aviation engineering in Ukraine. These two congregations developed into megachurches attracting thousands of Ukrainians with their positive message and charismatic worship.

A few large congregations established in the late 1980s and early 1990s played a key role in spreading Pentecostal and Charismatic Christianity in Russia and neighbouring republics after the break-up of the Soviet Union. These congregations sponsored evangelistic campaigns and trained men to lead plant new congregations. (With very few exceptions, in the Russian Pentecostal tradition only men serve as pastors.) On its webpage New Testament Church (Perm) claims to have planted 200 congregations; some of these are in Perm region, others are in other Russian regions and republics including Tatarstan, Bashkortostan, Komi republic, Chelyabinsk, Saratov, and St. Petersburg. New Generation (Riga) claims to be the home church for 200 congregations in 15 countries, including Latvia, Russia, Ukraine, Belarus, Kazakhstan, Germany and USA. Embassy of God (Kiev) had 38 congregations in Ukraine and 18 in other countries, including four in Russia (Wanner 2010). Bethany (Krasnodar) 
has more than 50 daughter churches. Word of Life (Nizhnevartovsk) has founded more than 30 daughter churches, not only in Western Siberia, but also in the central Volga region and even as far away as India. Word of Life (Yerevan) had 27 daughter churches in 2009. Philadelphia (Izhevsk) claims to have founded 32 daughter churches in a period of twenty years in Udmurtia and neighbouring regions.

The Russian Orthodox Church felt threatened by the rapid growth of nonOrthodox confessions, especially neo-Charismatic churches, and successfully lobbied the Russian government into restricting the freedom of religion. In 1997 the Russian law "On Freedom of Conscience and Religious Associations" outlawed churches that had been established for less than 15 years, that is, all churches founded after 1983 . Thousands of newly founded Protestant churches managed to keep operating legally by registering through a few denominations that has existed for 15 years (most are registered either through Russian Church of Christians of Evangelical Faith (RCCEF), now headed by Bishop Eduard Grabovenko or Russian Association of Christians of Evangelical Faith (RACEF), headed by Bishop Sergei Ryakhovsky) (Aronson 2012: ${ }_{36}$ ). As a result, there are strictly speaking no non-denominational megachurches in Russia.

In practice, some of the most successful Russian congregations function as centres of their own denominations. These are registered in turn with the larger umbrella organisations for legal reasons. For example, Good News (Moscow) is the centre for the Good News Association of Pastors and Churches, to which more than 700 congregations belong, and which is affiliated with RACEF. Word of Life (Moscow) is centre for the Association of Churches of Faith in Russia; according to Aronson (2012: 36), 240 churches were affiliated with this association, which is also affiliated with RACE F. In addition to serving congregations in Russia, Word of Life (Moscow) also serves as organisational centre for congregations in Central Asia and Vietnam. The congregations founded by Philadelphia (Izhevsk) are part of the Regional Association of Philadelphia Churches, which in turn is part of the RCCEF. We find a similar development in Ukraine. Word of Life church in Donetsk became the centre for a new Pentecostal denomination, the Ukrainian Christian Evangelical Church. According to the homepage for Word of Life (Donetsk), 370 churches and religious organisations are affiliated with the UCEC.

Church buildings that clearly mark the presence of the church in the city is something that characterises several (but not all) of Russia's megachurches. Word of Life (Moscow) bought an old movie theater in 2006 which they have renovated, so that it seats 1,200. Good News (Moscow) inaugurated a new church building in 2014; it is the largest Protestant church complex in Moscow according to Lunkin (2017). These building projects are especially impressive 
considering the climate in which they were undertaken. In some parts of Russia, Orthodox officials have influenced politicians to limit the operations of Pentecostal congregations. Building a new church is an arduous process, from purchasing the land to acquiring building permits, and when they are built, all too often authorities shut them down for alleged code violations. Philadelphia (Izhevsk) finally opened their new church building in 2013; the building had been finished already in 2009, but local building inspectors found various reasons not to let the congregation use it for several years. Some megachurches have nurtured dreams of their own building for years, but have not been able to see these dreams reach fruition because of opposition of local politicians. This is the case of the 5,000 member strong Bethany church in Krasnodar. In another case, a megachurch had its own building and had begun constructing an even greater building, only to lose them both. Word of Life (Donetsk), was able to purchase a movie theater in 2006 that seated 1,00o people. The building served as its centre for worship, elementary school, adult education and administration. In order to support its rapid growth of membership, the congregation bought a plot of land, and began construction on a new church building which was supposed to seat 7,000 people. That building has yet to be completed. The war in eastern Ukraine abruptly changed the prospects for this congregation in August 2014, when Russian rebels took over their existing building.

\section{3}

\section{The Role of the Megachurch Pastors}

As is the case in megachurches in other parts of the world, Russian megachurches are pastor-focused (Ellingson 2009: 21). While all Russian megachurches are formally part of a denomination, in practice denominational control over the megachurch pastors is not so strong. Real power in the two largest Russian Pentecostal denominations (RCCEF, RACEF) is on the level of senior presbyters, the head pastors of large congregations (Lunkin 2003: 271). The two leading Pentecostal denominations in Russia differ in how centralised they are. RACEF functions more like an umbrella organisation, making it possible for smaller denominations to be legally registered. RCCEF is more centralised. The RCCEF rewards especially successful senior pastors with the title of bishop, thereby giving them a stake in the larger organisation. It was earlier the rule that when a person became senior bishop of the RCCEF he stepped down from his position in the local church, but when Eduard Grabovenko became head of the RCCEF in 2009 he stayed on as senior pastor of New Testament Church (Perm), showing how important to him his role as head pastor in that congregation still is. 
Church homepages relate stories of the church history which are largely the same as the story of the pastor's life. Typically the founding pastors in the megachurches continue to serve as senior pastor until they retire (two exceptions are Hillsong, Kiev and Word of Life, Moscow). Senior pastors are the authorities in their congregations. This is perhaps to be expected, considering that these pastors are usually also the ones who founded the congregation, and that they are the ones in the congregation that have been believers longest. This also fits Russian society, which is very hierarchical.

There are close connections between several of the pastors that head megachurches, even when they live in different countries. For example, Marsh and Tonoyan (2013: 190) note that Ledyaev (who heads a megachurch in Riga) and Adelaja (who headed one in Ukraine) were "close friends, exchanging visits to each other's churches quite frequently". The pastors in the Word of Life churches in Russia, Ukraine, and Armenia are in constant contact with their colleagues in Sweden. In the waning years of the Soviet Union and shortly after the various post-Soviet states became independent it was common for big name preachers (such as Lester Sumrall, Ulf Ekman, Benny Hinn) to visit congregations and to participate in large scale evangelistic events. These have become less common as Russia has become more restrictive in granting visas to westerners and as the novelty of Charismatic Christianity has worn off.

Russian megachurch pastors are visionary leaders. Miller writes that it is typical that Pentecostal megachurches have "what might even be perceived as completely unrealistic goals and ambitions"; "the charismatic leaders of large Pentecostal mega-churches tend to thrive on 'big ideas' related to building projects, saving 'unreached' peoples, and planting new churches" (Miller 2014: 5). The pastor's vision drives the congregation. Many of the visions of Russian and Ukrainian megachurch pastors have been connected with planting churches all over the former Soviet Union, trying to undo the results of 70 years of Communist anti-religious policies. The large networks of daughter churches point at their success. But visions do not only have to be connected to planting churches. Grabovenko (New Testament, Perm) explains in a web interview that he began developing a model for home groups for his church on the basis of revelation. In response to a question about whether he wanted to participate in a specific project directed at businessmen, Grabovenko explained he was not interested: "When there is no revelation, it is useless to do anything". Simonyan, senior pastor at Word of Life (Yerevan), has explained to his congregation that he started doing television broadcasts because God told him to do so (Ohanjanyan 2014: 111-112).

Seemingly unrealistic visions have characterised the work of future megachurch pastors from the beginning. They took considerable risks when they 
first began their ministries. Several of these men did not seem adequately prepared for the job - Grabovenko and Rudenkii had attended Calvary Bible Institute in Jelgava, Latvia, for only half a year when they left to establish new congregations, but they were convinced they had a divine calling and that was motivation enough. Bishop Grabovenko, founder of the New Testament megachurch in Perm, relates that when he was finishing his studies in Jelgava, he prayed to be sent to a city in Russia that no one else wanted to go to. Perm was known as an especially inhospitable city; the Perm region hosted prisons and labour camps. Together with some fellow missionaries he moved to Perm, although he did not know anyone there, and started preaching the gospel. The congregation began as a home group, and expanded until they could afford to buy the local Palace of Culture. The congregations were expected to support themselves from the start.

While most Russian megachurches operate in areas where ethnic Russians are in the majority, Hosanna Church in Dagestan's capital Makhachkala ministered mainly to people of a nominally Muslim background. Islam also developed significantly after the break-up of the Soviet Union, and in some areas militant Islam has set root. In Dagestan (a republic in the Russian Federation located in the North Caucasus) 83 percent of the population identifies as Muslim. Artur Suleimanov, an Avar by ethnicity, founded Hosanna Church in 1994. Like many other megachurches it had ministries directed toward alcoholics and drug addicts and supported orphanages in the area. Unlike pastors of other churches, Suleimanov focused on evangelising nominal Muslims. He had considerable success; it has been estimated that his church had 2,00o members in 2010 and that 80 percent of the church members were of Muslim background. ${ }^{32}$ Suleimanov had been repeatedly threatened by militant Muslims, and on 15 July 2010 he was shot dead as he was leaving the church building. Although his murderer was never caught, it is thought that his murder was religiously motivated. While the church previously is said to have had 2,000 members, now services normally attract only about 600 people. According to Roshchin et al. (2014: 528), many who attend home groups do not attend the main services, because they fear the reaction of Muslim neighbours and family members.

On the whole, megachurch pastors in the former Soviet Union seem well disciplined and scandals have been few. There have been a couple economic scandals connected to megachurches here, however. The most notable case was that of Sunday Adelaja of The Embassy of God (Kiev) who was accused of running a Ponzi scheme called King's Capital that cheated people out of 100 million USD. He was later defrocked on other charges, having been accused of having affairs with several women in his congregation (Weber 2016). In the 
case of Word of Life (Donetsk), the Swedish mother church and elders in the local congregation broke off contact with Pastor Leonid Padun in 2012 because of what they considered to be financial irregularities. Padun refused to step down from his post, instead leading a schism. Considering the power inherent in being senior pastor of a megachurch, it is noteworthy that there have not been more scandals. Unfortunately, the scandals that have occurred come in handy for members of the Russian Orthodox hierarchy that seek to portray Neo-Charismatic Christianity in the darkest of colours.

\section{Doctrine}

As is the case in other parts of the world, Russian megachurches are affiliated with evangelical denominations. They all consider the Bible to be the ultimate authority in questions of faith, and all teach that individuals must make conscious decisions to follow Christ and be baptised as believers. This is something that sets them apart from the dominant Russian Orthodox Church, which practices infant baptism and claims the Russian people as its own, whether they identify themselves as believers or not. The Russian Orthodox Church considers Russian people to belong to its 'canonical territory' because historically it was this form of Christianity that first reached them. They accuse other Christian denominations (both Catholic and Protestant) who work among Russians of proselytising (Fagan 2013: 110-122).

All the megachurches studied here would be classified as Pentecostal or Charismatic. They believe that the Holy Spirit is active in the church today just as he was in apostolic times. People are encouraged to seek to be baptised in the Holy Spirit. Spirit baptism is said to be manifested through speaking in tongues (Marsh and Tonoyan 2013: 183). Prayers for physical healing are commonplace.

Several megachurches have connections to the Faith movement. There is a greater expectation here that individuals can receive new revelation than is the case in traditional Pentecostal churches. There is also an understanding in the Faith movement that God wishes for people to flourish spiritually, physically and materially, and that these blessings are available to those who ask in faith (Coleman 2000). Three of the megachurches studied here (Word of Life Moscow, Donetsk and Yerevan) were founded by the Russian Inland Mission, a project of the Swedish Word of Life church in Uppsala. This mission was founded as the result of a vision its head pastor Ulf Ekman had, and which was related to his followers. The Russia Inland Mission contributed to the establishment of hundreds of congregations in Russia and the former Soviet Union, and spread Faith teaching throughout the country. In addition to 
sending Scandinavian missionaries to Russia, Word of Life (Uppsala) provided theological education in Sweden for pastors from various parts of the Soviet Union, before establishing a Bible Institute in Moscow, which helped spread Faith teaching. Grabovenko (of New Testament, Perm) claims to have studied with Ulf Ekman, and Dirienko of Church of God (Yaroslavl) was inspired by Ekman to found his church.

When these Charismatic congregations were first being established, many pastors preached the prosperity gospel, including Renner of Good News, Moscow; Ledyaev of New Generation, Riga; Dirienko of New Generation, Yaroslavl (Lunkin 2009: 856); and Adelaja of the Embassy of God (Wanner 2007: 235). For example, Good News (Moscow) professes, "we believe that God wants to and can bless you with material prosperity" (Lunkin 2017). Word of Life (Moscow) is centre for the Association of Christians of the Evangelical Faith "Churches of Faith". The tenth article of its statement of faith spoke of full prosperity (“полное процветание”):

By his life, death and resurrection Jesus showed that God wants to save the individual in his spirit, soul and body, and that God's will is this, that every person in his life would walk in Divine health, Divine prosperity, [and] that he through faith would be a victor in all areas of life: spiritually; in his soul, physically, economically, socially.

To people who had been raised in a Soviet system that only warned of the dangers of capitalism while failing to fulfill its own promises of the perfect life, this was a refreshing message. Over time, as the promises of worldly prosperity failed to come true for most people, and as their theological thinking matured, Russian megachurches have changed their message (Marsh and Tonoyan 2013: 190). Today Word of Life churches emphasise that wealth is not a goal in itself, but should be used to build spread the kingdom of God.

While the prosperity gospel is not central to Russian megachurches today, they still have a positive attitude toward wealth as an instrument of blessing. They maintain good ties to members of the business community and offer classes in leadership and entrepreneurship, to help people establish businesses (cf. Marsh and Tonoyan 2013: 190-191). For example, Grace of Jesus Christ (Volgograd) links to an interdenominational network for Christian businessmen in the city that is hosted by the congregation. Connections with local businesses increase the possibilities for these congregations to make a positive impact in their communities.

Congregations connected to the Faith movement put more emphasis on tithing than do other churches. While tithing is common among Evangelicals 
in the West, it was something foreign to many in the former Soviet Union (Chervonenko 2017; Wanner 2007: 183). Pastors who successfully taught their congregation to tithe (by for example tying it to promises of future prosperity) had an advantage over traditional Pentecostal pastors, whose congregations could not afford to pay their salary. This contributed to their ability to grow, develop new ministries and plant new congregations. Since tithing has been a new thing for many Russians, some have looked at it with deep suspicion. For example, rebels in eastern Ukraine accused Protestants who advocate tithing of stealing money from people. The financial success of Charismatic megachurches contributes to the hostility shown by the Russian Orthodox Church, which had long charged that these 'western' churches enjoyed an unfair economic advantage.

\section{5 \\ Ministries}

Megachurches in Russia and other parts of the former Soviet Union are all seeker-friendly. The congregations were established as missionary endeavors, with the goal of reaching as many people as possible with the Gospel. Word of Life (Yerevan) says on its homepage: "we accept all the <sic > visitors with an open heart and are always ready to answer all your questions and, in case of need, pray for you". They are not bound by older evangelical traditions, but are heavily influenced by the worship style of western Charismatics. Informal dress is acceptable in Russian megachurches, and unlike what is the case in older Russian Pentecostal congregations and the Russian Orthodox Church, women are not expected to cover their heads in church (Marsh and Tonoyan 2013: 185).

Contemporary worship styles are the norm in Russian megachurches. Many of the same songs can be heard here as in Charismatic churches in the western world. This may have contributed to their popularity early on - the missionaries that founded the churches brought with them music styles inspired by popular culture from the West that allowed for a greater display of emotion than what was common in traditional Pentecostal churches. Worship leaders had a key role in establishing and growing new congregations. Some megachurch pastors had a background as worship leaders. This includes Alexei Ledyaev who eventually became head pastor of New Generation (Riga, Latvia), and Leonid Padun, who headed Word of Life, Donetsk. For many churches, the music ministry is of central importance. As might be expected, this is the case with Hillsong, Kiev, just as it is to the mother congregation in Sydney, Australia. Although it initially met with some resistance among traditional Pentecostals in Russia, contemporary worship has become widely accepted today, and it is 
used even in more traditional Pentecostal and Baptist congregations. This style of worship is completely unlike that found in Russian Orthodox Churches, however, whose leaders disparage it as a western import that is damaging to Russian culture.

Since the congregations are so large, megachurches offer several services on the weekends; in the case of New Testament, Perm, services are held every day of the week. Some also offer services in other languages, for immigrants or members of Russia's larger minority peoples. Word of Life (Moscow) offers four Russian-language services per weekend, in addition to an English language service, a Chinese service and a Vietnamese service, for example. They have also offered services in Armenian since 2013. Bethany (Krasnodar) has services in Russian and Armenian.

All Russian megachurches emphasise how important weekly small group meetings are to their overall ministry. Good News (Moscow) has more than 200 small groups in Moscow (Lunkin 2017). Grabovenko of New Testament Church (Perm) is inspired by the Korean pastor Yongghi Cho whose megachurch builds on small groups; Grabovenko's church included 170 small groups. In a web-interview on his church's homepage (February 2011) he explains that this method works for his congregation, but is not necessarily the right approach for all churches. For some congregations small groups are absolutely vital. Bethany (Krasnodar) had 5,000 members in 2014, but could not get access to a building where the congregation could gather for worship, instead its 300 home churches become the place where the church worships. Hosanna church in Makhachkala has also increasingly localised its work to home churches, as their members are freer to worship without being threatened by militant Islamists.

Most megachurches in Russia are involved in social ministries. A Pentecostal bishop explained that when he first established his congregation, social ministries were not what he had anticipated would come to define his church. But that was the reality that the congregation faced. In the waning years of the Soviet Union and the early days of independence, the state had little to offer those who were on the margins of society.

As these churches are all in the Pentecostal tradition, prayer for healing is normal. In the neo-charismatic megachurches prayers for healing are more dramatic than in traditional Pentecostal services, however. Russian neocharismatic congregations have supported 'faith healing crusades', where people seek prayer for healing on stage in front of a large audience (cf. Marsh and Tonoyan 2013: 185).

Drug and alcohol rehabilitation is a central ministry for megachurches in Russia and other former Soviet republics. People with addiction problems 
turned to the Pentecostals who welcomed them. Their conviction that people can start anew, that people can be rid of their addictions as they are born again was attractive. The strict moral rules of the Pentecostals, including complete prohibition on drinking alcohol, provided an atmosphere where people could be freed from their vices. These recovering alcoholics are strongly encouraged to stay active in the churches, and some have risen to leadership positions. Former alcoholics and drug addicts and their families were the core of the Embassy of God, for example. Half of its pastors used to be addicts (Wanner 2007: 212, 222).

Many of the Protestant megachurches in Russia and Ukraine are engaged in prison ministries; these include New Testament (Perm); Church of the Covenant (Novosibirsk); Grace of Jesus Christ (Volgograd). The prison population in Russia is large, and the Russian Orthodox Church had not showed much interest in serving this section of the population. New Testament Church in Perm had made this into one of their specialties; after all, in 2001 there were 100,000 convicts in the Perm region. The congregation supports evangelisation within the prisons as well as offering material and spiritual support for the families of inmates. Recently in some areas local government officials have restricted the possibilities of Protestant congregations to ministering to prisoners. Word of Life in Donetsk ran prison ministries, but were forced to cease operating in prisons when Russian rebels that identified as Orthodox took over the area in 2014. Hosanna church in Makhachkala had also been engaged in prison ministries with the approval of the local government in Dagestan since 2,00o, but in 2010, even before Suleimanov was killed, government authorities abruptly prohibited them from making further prison visits (Fagan 2010; Roshchin et al. 2014: 528). Apparently these prison ministries were too successful in turning criminals into Protestants.

Bible Schools

The larger Word of Life congregations in the former Soviet Union hosted Bible Institutes, following the model of the Swedish mother church, to train new pastors, missionaries and congregational leaders. The Bible Center at Word of Life Moscow was established in 1994. In 2009 close to 6,00o students were said to have studied there. Word of Life Yerevan offers nine month and three month Bible schools, and also internet Bible school, Word of Life church in Donetsk ran a Bible Institute which was established in 1993. More than 4,6oo students graduated from the Donetsk Bible School, and many went on to found and lead congregations. Because they had dynamic lecturers, and because there were 
few theological seminaries to choose from, Bible schools run by Word of Life also attracted Christians who did not belong to the Faith tradition, including people who went on to serve as pastors in traditional Pentecostal congregations associated with RCCEF. New Testament (Perm), Grace of Jesus Christ (Volgograd), and Hillsong (Kiev) also run Bible schools. Unlike what is the case in megachurches elsewhere, Russian megachurch pastors are not prolific writers. The publication of books is not a central part of their ministry. Their emphasis is on evangelisation, social ministries and church planting. Because Russian Charismatic leaders have not focused on formulating theology, the theology that is taught in the Bible schools run by megachurches has mainly been developed in the West (Sawatsky 2010: 26).

Some churches have developed television ministries. These include Bethany (Krasnodar), New Generation, Embassy of God (Kiev), and Word of Life (Yerevan). The quality of the churches homepages vary. One congregation that has been especially successful in its internet ministry is Good News (Moscow), which according to Lunkin (2017) attracts more than 12,00o regular visitors. In some areas people gather together to watch live broadcasts of their services on the net, thus forming small satellite congregations.

Political Activity

In Ukraine most denominations with the exception of the Russian Orthodox Church (Moscow Patriarchate) supported the Orange Revolution (2004-2005) (Wanner 2010). Local politicians have been active in megachurches in Kiev, at times using them as a power base. A notable example is Leonid Chernovetskyi, mayor of Kiev 2006-2012, who was a member of the Embassy of God and a supporter of the Orange Revolution. In an interview quoted by Wanner, Chernovetskyi says that his becoming a member of Embassy of God was conditional on the congregation helping him run for office (Fagan 2013: 107; Wanner 2007: 236-239). The Russian government does not wish to see anything comparable to the Orange Revolution happening in its country. In the wake of the Orange Revolution they became more restrictive in allowing foreign-based preachers work in Russia. Fagan reports that Adelaja of the Embassy of God was deported from Russia "in the interests of state security" in 2006. Ledyaev of New Generation (Riga) who, like Adelaja, encouraged his parishioners to be politically active, was deported from Russia already in 2002 (Fagan 2013: 107-108). As a result, Russian megachurch pastors are less likely to openly support individual candidates or to criticise the Russian government than their counterparts elsewhere. They teach the importance of good morals and obeying the law. Their 
emphasis on family values matches that of the Russian state and they seek to work together with the Russian Orthodox Church in this area. They encourage patriotism, and unlike what was the case among Pentecostals in the Soviet era, church members are not discouraged from doing armed service. They are still looked upon with distrust by government officials both on regional and central levels, however.

The low-grade war in eastern Ukraine has been problematic for Russian megachurches, as many pastors have relatives in Ukraine. They have been careful to explain that they do not side with Ukraine in that war. In spite of the diplomatic approach taken by most megachurches in Russia, hierarchs in the Russian Orthodox Church continue to paint neo-Charismatic churches as a dangerous foreign influence, however.

The Contemporary Situation

In preparing this chapter I contacted several Russian denominations and church leaders but received few answers. One reason for this is that Protestant churches have come under increasing pressure from the Russian government. The establishment religion in many of the post-Soviet states is Orthodox (in Russia and Belarus it is the Russian Orthodox Church, Moscow Patriarchate, and in Armenia, the Armenian Apostolic Church). Orthodox churches consider Protestant denominations, and Pentecostals in particular, to be sectarian, and they are often portrayed as foreign totalitarian sects (Fagan 2013: 96-111). This is the same propaganda as the Communist party had spread in the Soviet era. Many Russians put Pentecostals and Jehovah's Witnesses in the same category; they know nothing about the denominations, but consider them foreign and dangerous (Kääriäinen and Furman 2000).

While there were few restrictions on religious freedom in the early 1990s, spokesmen for the Russian Orthodox Church have continually lobbied the Russian parliament to restrict activities of Protestant churches. In recent years these restrictions have become more serious. The so-called Yarovaya law (20 July 2016) restricted activities of missionaries and on practicing religion anywhere but in a formal place of worship. The laws are unclearly formulated and their application is not systematic. They may imply that home churches and even internet-based religious practices are now illegal. A strict interpretation of the laws would severely limit the possibility of all religious groups, including megachurches, to operate.

It is difficult to speculate regarding the future prospects of megachurches in Russia. Considering how few practicing Christians of any denomination there are in the country there is considerable room for growth. Megachurches in the 
large cities are especially well positioned to tap into this growth potential, as they can employ teams of well-trained preachers and musicians who offer dynamic preaching and well-orchestrated worship. Congregational members are dependent on functioning home groups to have their private spiritual needs met, however, and recently passed laws seem to call the legality of such home groups into question. If it does become illegal to host homegroups, larger congregations will suffer.

In July 2017 the Russian Supreme Court found that Jehovah's Witnesses were an 'extremist' organisation, and upheld the Russian Parliament's decision to confiscate their property. Might the same thing happen to Pentecostals? The new buildings built by megachurches are a visible reminder of Protestant presence in Russian cities. Some might hope that if the congregations are large enough, the state will not interfere with their ministries. The fact that proRussian militants affiliated with Orthodox militias took over the Word of Life megachurch in Donetsk (eastern Ukraine) and converted it into military headquarters suggests size is no guarantee of safety (Mitrokhin 2015). The action may have been intended to send a message to neo-Charismatic megachurches in Russia proper. If the Orthodox Church continues to grow in influence in Russia, and if Russian nationalists continue to colour Church policies, megachurches may choose to keep a lower profile.

As was mentioned, Russian megachurches were influenced by the western world in their message, music, architecture and much more. Increasing tensions with the West may cause more Russians to look upon megachurches with distrust. On the other hand, young people who have grown up in the post-Soviet era may have fewer prejudices regarding religious organisations in general and regarding Evangelicals in particular. The Orthodox Church's quest for a religious monopoly is likely to backfire. As megachurches have over time become more Russian in terms of their leadership, message and music, and as they have been socially active, continually showing with concrete actions their love for people, especially for those on the margins of society, attempts to besmirch them are not likely to be as successful as the propaganda directed against Jehovah's Witnesses. Although individual congregations may face difficulties in the immediate future, it is likely that megachurches in Russia will generally experience continued growth and that new congregations will join their ranks.

\section{References}

Aronson, T. 2012. "Continuity in Charismata: Swedish Mission and the Growth of NeoPentecostal Churches in Russia." Occasional Papers on Religion in Eastern Europe. 31:3, 32-40. 
Burdo (Bourdeaux), M. and Filatov, S. eds, 2005, 2006, 2009. Атлас современной религиозной жизни России, volumes 1,2,3. Moscow: Keston Institute.

Chervonenko, S. 2017. Stewardship in the Church: The Theology and Practice of Tithing, Offerings and Stewardship in Evangelical Churches of Russia. Asbury Theological Seminary.

Ellingson, S. 2009. "The Rise of the Megachurches and Changes in Religious Culture: Review Article." Sociology Compass. 3:1, 16-30.

Fagan, G. 2010. "Russia: Ghostlike Existence for Dagestani's Protestants." Forum 18.

Fagan, G. 2013. Believing in Russia: Religious Policy after Communism. Abingdon: Routledge.

Filatov, S. ed, 2014, 2016. Религиозно-общественная жизнь российских регионов, volumes 1 and 2. Moscow: Letnii Sad.

Kääriäinen, K. and Furman, D. 2000. "Religiosity in Russia in the 1990s." In M. Kotiranta, ed, Religious Transition in Russia. Helsinki: Kikimora, 28-75.

Knox, Z. 2005. Russian Society and the Orthodox Church: Religion in Russia after Communism. London: Routledge.

Löfstedt, T. 2012. "Religious Revival among Orthodox and Pentecostals in Russia: Causes and Limitations." Religion, State \& Society. 40:1, 92-111.

Lunkin, R. 2003. “Пятидесятничество и харизматическое движение.” In M. Burdo (Bourdeaux) and S. Filatov, eds, Современная религиозная жизнь России, volume 2. Moscow: Logos, 241-283.

Lunkin, R. 2009. “Ярославская область.” In M. Burdo and S. Filatov, eds, Атлас современной религиозной жизни России, vol 3. Moscow: Keston Institute, $832-863$.

Lunkin, R. 2014. "Российский протестантизм: евангелчские христиане как новый социальный феномен." Современная Европа. 3:59, 133-143.

Lunkin, R. 2017. "Церковь мегаполиса: христианская миссия в разных пространствах." Russian Review/ Русское ревью. 72 (June 2017).

Marsh, C. and Tonoyan, A. 2013. "The Routinization of Soviet Pentecostalism and the Liberation of Charisma in Russia and Ukraine." In R.W. Hefner, ed, Global Pentecostalism in the 21st Century. Bloomington: Indiana University Press, 176-193.

Miller, D.E. 2014. "Where the Spirit Leads: Pentecostalism and Freedom." Paper given at the Religious Freedom Project, Georgetown University's Berkeley Center for Religion and the Institute for Studies of Religion at Baylor University, 15/6/14.

Mitrokhin, N. 2015. "Infiltration, Instruction, Invasion: Russia's War in the Donbass." Journal of Soviet and Post-Soviet Politics and Society. 1:1, 219-249.

Ohanjanyan, A. 2014. "Evangelical and Pentecostal Communities in Armenia: Negotiating Identity and Accomodation." In A. Agadjanian, ed, Armenian Christianity Today: Identity Politics and Popular Practice. London: Routledge, 91-121. 
Roshchin, M., Lunkin, R. Filatov, S. 2014. “Республика Дагестан.” In S. Filatov, ed, Религиозно-общественная жизнь русских регионов, vol 1. Moscow, St. Petersburg: Letnii Sad, $\mathbf{5}^{20-548 .}$

Sawatsky, W. 2010. "Reflections on the Urgency of Theological Education in the Former Soviet Union: After 20 Years." Religion in Eastern Europe. 30:2, 20-26.

Wanner, C. 2004. "Missionaries of Faith and Culture: Evangelical Encounters in Ukraine." Slavic Review. 63:4, 732-755.

Wanner, C. 2007. Communities of the Converted: Ukrainians and Global Evangelism. Ithaca: Cornell University Press.

Wanner, C. 2009. "Missionaries and Pluralism: How the Law Changed the Religious Landscape in Ukraine." In L.Z. Onyshkevych and M.G. Rewakowicz, eds, Contemporary Ukraine on the Cultural Map of Europe. Armonk, NY: M.E. Sharpe, 89-100.

Wanner, C. 2010. "Social Ministry and Missions in Ukrainian Mega Churches: Two Case Studies." East-West Church Ministry Report. 18:4, 12-14.

Wanner, C. 2010. "Up and out: Movement and Mobility among Pentecostals in Eurasia." PentecoStudies. 9:1, 195-210.

Weber, J. 2016. "Will Europe's Third-Largest Church Punish Pastor for Multiple Affairs? Sunday Adelaja loses leaders at Kiev's Embassy of God for not heeding their discipline." Christianity Today. 17 May. http://www.christianitytoday.com/news/2016/ may/will-embassy-of-god-punish-sunday-adelaja-multiple-affairs.html. 